\title{
Regional Business Education Issues: South Texas Employers And Faculty Rate Communication And Technology Skills
}

Ashley Bennington, (Email: kfajb00@tamuk.edu), Texas A\&M University, Kingsville

\begin{abstract}
Business communication courses teach written and oral communication skills with an emphasis on using technology. With a goal of meeting stakeholder needs, this study asks 221 South Texas employers and 212 faculty members of a regional university to rate employees' and students' communication skill competencies. The survey asked 12 questions-four about written competencies, five on verbal, and three on technology skills. Employers consistently rated employees higher than faculty rated students. The ratings offer implications for the business communication course: Employers and faculty are satisfied with technology skills, but basic grammar and punctuation need improvement.
\end{abstract}

\section{BACKGROUND AND CONTEXT}

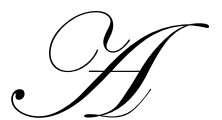

business communication course anticipates students will develop written and oral communication skills that will assist them along their career paths. Over the past several years, studies have shown a shift in emphasis of what employers seek in new employees. As instructors and researchers, we must continuously monitor what specific communication skills to emphasize.

In a meta-analysis of several studies conducted in 14 different countries, Billing (2003) identified and compared key skills that employers expect of higher education graduates; discipline specific skills were no longer the priority emphasized by employers. Billing found that communication skills ranked at the top. Another analysis refers to this as an employer shift toward "generic skills" such as communication, technology literacy, and teamwork as crucial for employees (Dench, 1997).

Employers consistently identify communication skills (written and oral) as critical for employee and business success. In addition to employer expectations, institutions must be responsive to accreditation requirements. A major accrediting organization-Association to Advance Collegiate Schools of Business International (AACSB) - has identified communication abilities as important general skills for institutions to incorporate into program learning outcomes and assessment (2004).

Business communication textbooks generally agree on the critical topics to be covered in the business communication course: employment communication, report writing, business correspondence, and oral presentations. Wardrope \& Bayless, (1999) confirm that business communication course syllabi reflect these topics

A study comparing business professionals and business faculty perceptions of the importance of business communication skills found there was no significant difference between the two groups (Waner, 1995). Waner concluded that the skills taught in the business communication course at her institution appropriately mirrored those deemed important in the business community. However, Waner also emphasized the need for ongoing evaluation of business communication course content with respect to competencies needed in the workplace.

One purpose of this research was to identify South Texas employers' perceptions of employees' business communication competencies to assist in the assessment of learning outcomes in the business communication course 
at Texas A\&M University-Kingsville (TAMUK). Most TAMUK students are from South Texas and approximately $61 \%$ of the students are Hispanic. Most students indicate they will remain in the region when they graduate, meaning we are preparing several hundred students every year for jobs with South Texas employers.

One premise of this study was that students seeking degrees that will support their career goals not only need to develop good communication skills for their future employment, but also for their success in the coursework that will earn them discipline-specific degrees. As such, the study also examined faculty perceptions of students' communication skill competencies.

\section{METHODOLOGY}

Two survey forms were developed for this study - one for employer responses and one for faculty responses. Twelve questions were constructed to ascertain respondents' ratings of employee and student communication skills. Using a scale of 1-poor, 2-acceptable, and 3-good, four questions were asked about written skills, five about oral skills, and three about technology skills. Each of the questions was identical with the word "student" or "employee" inserted. See Appendix A for the wording of each question.

Data were collected by undergraduate students during the fall 2003 semester. Students in four sections of Business Communication (BCOM 3304) at TAMUK were assigned to gather two completed surveys each. Organized in groups of three to five students, each group was expected to obtain an equal number of responses from faculty and employers. Students were instructed to identify employer respondents who had supervisory responsibilities. A total of 221 employers and 212 faculty surveys were completed.

\section{FINDINGS}

Table 1 shows the means obtained for employer and faculty ratings for each item. The total "poor," "acceptable," and "good" responses for each item was calculated and divided by the actual number of responses for each item.

\section{Table 1}

\section{Individual Skill Ratings}

(scale: 1 = poor; 2 = acceptable; 3 = good)

\begin{tabular}{|c|c|c|}
\hline Skill & $\begin{array}{l}\text { Employer } \\
\text { Rating }\end{array}$ & $\begin{array}{r}\text { Faculty } \\
\text { Rating }\end{array}$ \\
\hline \multicolumn{3}{|l|}{ Writing Skills } \\
\hline Preparedness & 2.4312 & 1.7861 \\
\hline Clarity and Coherence & 2.4155 & 1.7800 \\
\hline Grammar and Punctuation & 2.3272 & 1.6850 \\
\hline Overall Writing Skill & 2.4128 & 1.7550 \\
\hline \multicolumn{3}{|l|}{ Verbal Skills } \\
\hline Clarity and Projection & 2.5928 & 2.0905 \\
\hline Delivery and Style & 2.5249 & 1.9710 \\
\hline Articulation & 2.4455 & 1.8469 \\
\hline Content Quality & 2.5545 & 2.0433 \\
\hline Overall Verbal Skill & 2.5455 & 2.0284 \\
\hline \multicolumn{3}{|l|}{ Technology } \\
\hline Preparation & 2.3825 & 2.1823 \\
\hline Electronic Communication & 2.4558 & 2.3048 \\
\hline Skill Adaptability & 2.4977 & 2.2921 \\
\hline
\end{tabular}


The means shown in Table 1 for employer ratings were "acceptable" or "good" for all 12 items; means for faculty ratings were below "acceptable" for six of the 12 items.

Table 2 shows the percent of employer and faculty responses for each of the 12 items.

Table 2

Percent Ratings Employers

(Emp) and Faculty (Fac)

\begin{tabular}{lrrrrrr}
\hline \multirow{2}{*}{ Skill } & \multicolumn{2}{c}{ Poor } & \multicolumn{2}{c}{ Acceptable } & \multicolumn{2}{c}{ Good } \\
\hline Writing Skills & Emp & Fac & Emp & Fac & Emp & Fac \\
$\quad$ Preparedness & & & & & & \\
$\quad$ Clarity and Coherence & 3.2 & 32.3 & 50.5 & 56.7 & 46.3 & 10.9 \\
$\quad 5.5$ & 32.0 & 47.5 & 58.0 & 47.0 & 10.0 \\
$\quad$ Grammar and Punctuation & 11.1 & 40.5 & 45.2 & 50.5 & 43.8 & 9.0 \\
$\quad$ Overall Writing Skill & 5.0 & 33.0 & 46.8 & 58.5 & 47.2 & 8.5 \\
& & & & & & \\
Verbal Skills & & & & & & \\
$\quad$ Clarity and Projection & 2.7 & 11.9 & 35.3 & 67.1 & 62.0 & 21.0 \\
$\quad$ Delivery and Style & 3.6 & 18.8 & 40.3 & 65.2 & 56.1 & 15.9 \\
$\quad$ Articulation & 5.5 & 26.3 & 44.5 & 62.7 & 50.0 & 11.0 \\
$\quad$ Content Quality & 3.2 & 13.5 & 38.2 & 68.8 & 58.6 & 17.8 \\
$\quad$ Overall Verbal Skill & 3.2 & 12.8 & 39.1 & 71.6 & 57.7 & 15.6 \\
$\quad$ & & & & & & \\
Technology & & & & & & \\
$\quad$ Preparation & 8.3 & 10.4 & 45.2 & 60.9 & 46.5 & 28.6 \\
$\quad$ Electronic Communication & 6.0 & 7.5 & 42.3 & 54.5 & 51.6 & 38.0 \\
$\quad$ Skill Adaptability & 5.5 & 3.4 & 39.2 & 64.0 & 55.3 & 32.6 \\
& & & & & & \\
\hline
\end{tabular}

The percentages shown in Table 2 for each rating on the individual items provides a clearer picture of the employers and the faculty assessments of communication skills. Employers rating each item as "poor" ranged from $2.7 \%$ to $11 . \%$; faculty respondents rating each item as "poor" ranged from $3.4 \%$ to $40.5 \%$. Employers rating each items as "acceptable" ranged from $35.3 \%$ to $50.5 \%$; faculty rating each item as "acceptable" ranged from $50.5 \%$ to $71.6 \%$. Employers rating each item as "good" ranged from $46.3 \%$ to $6 \%$; faculty rating each item as "good" ranged from $8.5 \%$ to $38 \%$.

\section{DISCUSSION}

The employers' ratings averaged between acceptable and good for all twelve questions. Combining the related skill questions, figure 1 illustrates the average ratings ( 1 poor, 2 acceptable, 3 good) for each of the three composite skill groups - written, verbal, and technology. Because the survey did not specify ratings for entry-level employees, one possible explanation could be that employees had time and experience to develop these skills.

The employer ratings were higher than faculty ratings for each of the twelve items; however between-group comparisons cannot be accurately drawn because convenience sampling was used to gather responses. Although the lower ratings from faculty might be expected, the faculty ratings tend to reflect the same emphases as those of employers. The ratings from employers and faculty have implications for the TAMUK business communication course content. 
Figure 1 charts the average responses (on a scale of 1-poor, 2-acceptable, 3-good) of employers and faculty as a composite the items in each of the three business communication skill categories - written skills, verbal skills, and technology skills.

Figure 1

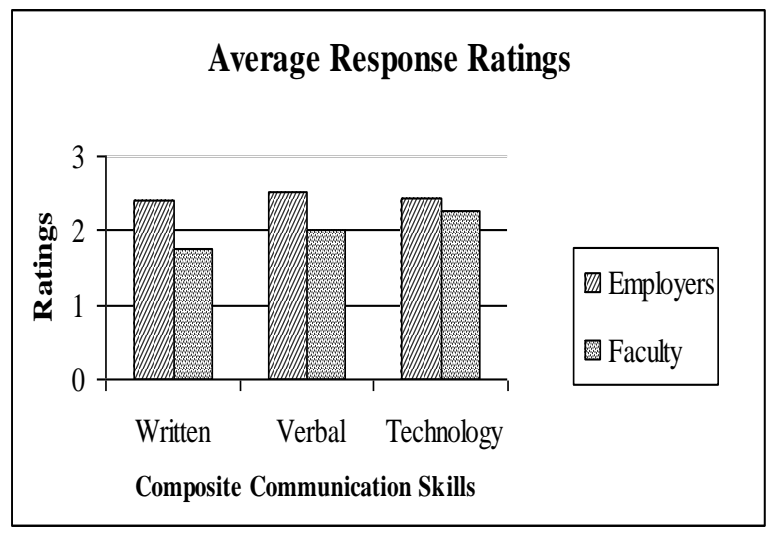

Figure 1 shows the average ratings from each group for technology skills as above acceptable. As indicated in Table 1, the highest average rating from employers was for verbal clarity and projection (2.593 mean). The lowest average rating from employers was for written grammar and punctuation (2.327 mean). Employee verbal clarity and projection received the highest average rating (2.593 mean). Faculty also indicated the written grammar and punctuation skills of students were the weakest, averaging between poor and acceptable (1.685 mean). Students' electronic communication skills were rated the highest by faculty ( 2.305 mean).

Because the rating scale of 1-3 limits the range of options available for the evaluation, the averages are not as indicative as perhaps the quantitative ratings for each survey item as shown in Table 2-poor, acceptable, and good. In the figures that follow, the composites of survey items under each of the three skill categories - written, verbal, and technology - are charted by percent of respondents. These figures help the interpretation of each group, employers and faculty.

\section{Written Communication Skills}

Figure 2 charts the percent of respondents for the composite written skill items. Specifically, for each group of respondents the total good rating responses for the four survey items under the written skills category was divided by the number of respondents; the same calculation was made by group for the acceptable and poor ratings of written communication skills..

Written communication skills are the foundation of business communication learning objectives (Wardrope \& Bayless, 1999). Although both employers and faculty rated written grammar and punctuation skills the lowest of the twelve items (Table 1), only $11 \%$ of employers indicated the skill level of poor; $44 \%$ of employers indicated written grammar and punctuation skills as good for a combined total of $89 \%$ rated employees as acceptable to good. In contrast, nearly $41 \%$ of the faculty rated students' written grammar and punctuation skills as poor and only $9 \%$ of faculty respondents rated students' written grammar and punctuation skills as good.

\section{Verbal Communication Skills}

Although there was a shifting focus toward verbal communication skills identified in the 1980s (Swenson 1980), researchers in the 1990s (Tanyel, Mitchell, \& McAlum, 1999) found written business communication again becoming the highest priority due to changing technology use from telephone and face-to face communications to 
electronic text communication. This change does not eliminate the need for employees to be able to articulate their thoughts and communicate verbally in the workplace.

Figure 2

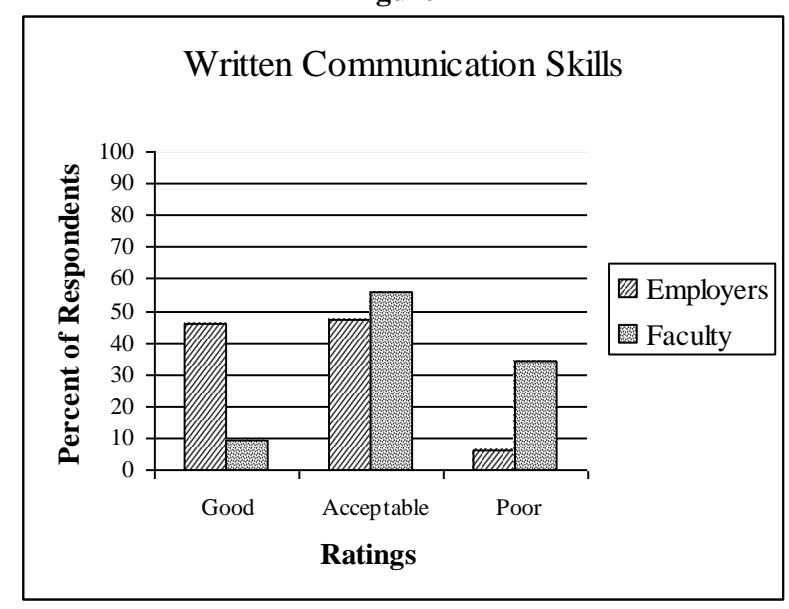

Figure 3 charts the percents of each groups' ratings for the composite of the five verbal communication skills survey items.

Figure 3

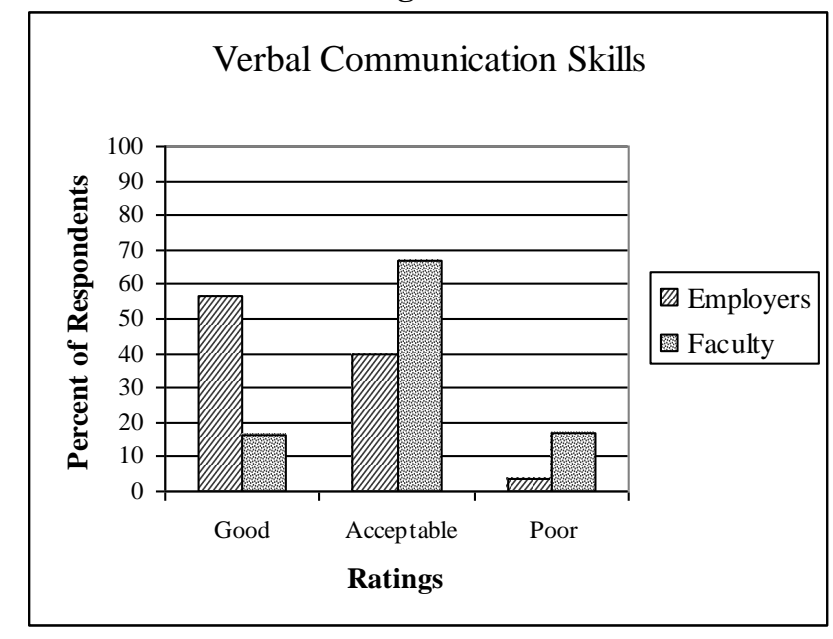

TAMUK is a minority serving institution with $61 \%$ Hispanic students in a South Texas region where a majority of the labor force is Hispanic. The higher ratings for employers' satisfaction with employees' verbal communication may reflect the oral tradition of the culture. There is not a comparable diversity in the university faculty. 


\section{Technology Skills}

Figure 4 charts the percent of respondents for the composite technology skill items.

Figure 4

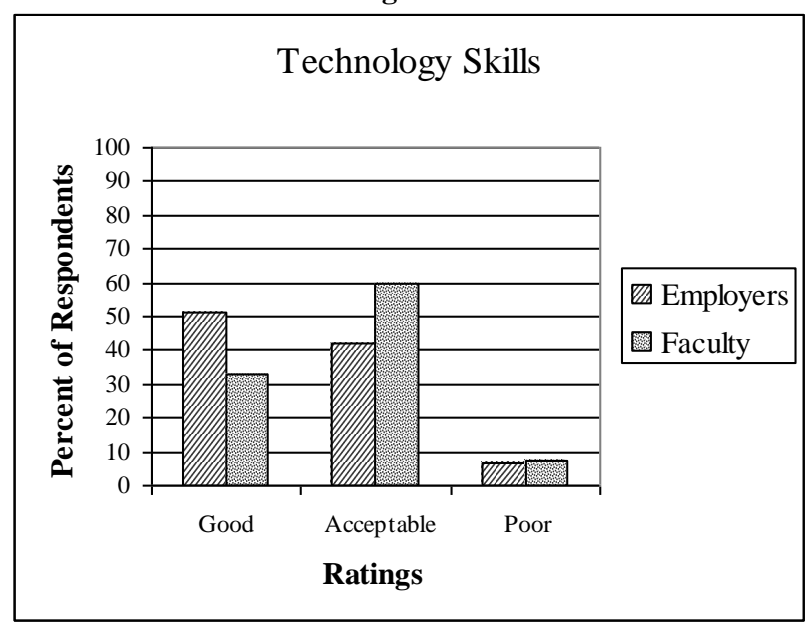

While employers and faculty showed disparity in their ratings of written and verbal communication skills, figure 4 shows that satisfaction in both groups' ratings of technology skills, particularly technology skill adaptability. Whether technology skills are being learned inside or outside the classroom, these results indicate that the institution is adequately exposing students to computer technology.

\section{Study Weaknesses}

Two key methodological weaknesses are sample representation of the two populations and survey validity. The faculty sample did not distinguish between adjuncts, instructors, and tenured or tenure track faculty. The employer sample was primarily drawn from student acquaintances; absent adequate representativeness, the two populations cannot accurately be compared.

We cannot learn from this study whether employees are actually better skilled than students. Both individually and collectively, what may be a good level of competency for one employer or faculty member may not meet the acceptable level of another. In order to specifically identify business communication skill weaknesses in graduates who become employed in the region, the employers of alumni could be identified and surveyed.

Bennett, Dunne, and Carré. (2000) argue that studies of transferability of cognitive skills show "little or no thought has been given to the theoretical or empirical base of the skills deemed necessary, or to their definition or to their underlying implicit assumptions (p.10)." The question of what respondents mean when they identify a communication skill and how skill levels should be defined and measured can vary greatly. The 1-3 point scale choices of poor, acceptable, and good may have precluded a statistical difference; however, the selection of these three terms was intended to reduce variations in respondents' interpretations of more specific distinctions.

\section{CONCLUSIONS AND RECOMMENDATIONS}

Business communication textbooks and course syllabi have adapted to the changing priorities over the past few decades. However, consistent with recent studies (e.g. Wardrope, 2002), this research supports the need to continue to focus on the writing basics. This study examined perceptions of the quality of business communication 
skills. Qualitative methods such as guided interviews or open ended questionnaires could provide greater specificity on what our students' audiences really want.

The results emphasize the importance of written communication skill development with particular emphasis on grammar and punctuation. Standardized skill assessments should be used to identify students who need additional language skill development prior to taking upper level courses. In order to take advantage of technological competency, perhaps grammar and punctuation skills can be developed through interactive computer activities.

The current TAMUK business communication course uses WebCT to deliver assignments, supplemental instruction, quizzes, and feedback on assignments, as well as to facilitate student-faculty communication and studentstudent communication for team projects. There is no indication from this study for increasing the current level of computer technology emphasis in the course.

The written, verbal, and technology skills deemed critical learning outcomes for business communication courses are clearly expected by students' audiences - employers and faculty. Several additional skills often covered in the business communication course were not examined here including teamwork, listening, and reading skills. As we juggle to cover so many different communication skills in one course, this study serves as a guideline for the TAMUK business communication course: emphasize writing, especially grammar and punctuation.

\section{APPENDIX A}

\section{Communication Skills Survey Questions}

Employers Survey

\begin{tabular}{|c|c|c|}
\hline & $\begin{array}{l}\text { Rate employee preparedness for writing required in your } \\
\text { organization? }\end{array}$ & $\begin{array}{l}\text { 1. Rate student preparedness for writing assignments required } \\
\text { in your classes? }\end{array}$ \\
\hline 2. & $\begin{array}{l}\text { How would you describe the clarity and coherence of } \\
\text { employees' writing? }\end{array}$ & $\begin{array}{l}\text { 2. How would you describe the clarity and coherence of } \\
\text { students' written assignments? }\end{array}$ \\
\hline & $\begin{array}{l}\text { What about employees' grammar and punctuation } \\
\text { competence? }\end{array}$ & $\begin{array}{l}\text { 3. What about students' grammar and punctuation } \\
\text { competence? }\end{array}$ \\
\hline & $\begin{array}{l}\text { Overall, how would you rate your employees' written } \\
\text { business communication skills? }\end{array}$ & $\begin{array}{l}\text { 4. Overall, how would you rate students' written } \\
\text { communication skills? }\end{array}$ \\
\hline & $\begin{array}{l}\text { How would you describe employees' speaking clarity } \\
\text { and projection? (Can their words be heard and } \\
\text { understood?) }\end{array}$ & $\begin{array}{l}\text { 5. How would you describe students' speaking clarity and } \\
\text { projection? (Can their words be heard and understood?) }\end{array}$ \\
\hline & $\begin{array}{l}\text { How would you describe physical delivery and style of } \\
\text { employees' oral communications? }\end{array}$ & $\begin{array}{l}\text { 6. How would you describe physical delivery and style of } \\
\text { students' oral communications? }\end{array}$ \\
\hline & $\begin{array}{l}\text { How would you describe employees' abilities to } \\
\text { coherently articulate points for their listeners? }\end{array}$ & $\begin{array}{l}\text { 7. How would you describe students' abilities to coherently } \\
\text { articulate points for their listeners? }\end{array}$ \\
\hline & $\begin{array}{l}\text { How would you rate the content of employees' verbal } \\
\text { communications? }\end{array}$ & $\begin{array}{l}\text { 8. How would you rate the content of students' verbal } \\
\text { communications? }\end{array}$ \\
\hline & $\begin{array}{l}\text { Overall, how would you rate employees' verbal } \\
\text { communication skills? }\end{array}$ & $\begin{array}{l}\text { 9. Overall, how would you rate students' verbal } \\
\text { communication skills? }\end{array}$ \\
\hline & $\begin{array}{l}\text { How would you rate the general level of employees' } \\
\text { technology preparation for their work functions? }\end{array}$ & $\begin{array}{l}\text { 10. How would you rate the general level of students' } \\
\text { technology preparation for your classes? }\end{array}$ \\
\hline & $\begin{array}{l}\text { How would you describe employees' use of electronic } \\
\text { communication? }\end{array}$ & $\begin{array}{l}\text { 11. How would you describe student use of electronic } \\
\text { communication? }\end{array}$ \\
\hline & $\begin{array}{l}\text { How do you rate the technological skill adaptability of } \\
\text { your employees? }\end{array}$ & $\begin{array}{l}\text { 12. How do you rate the technological skill improvement } \\
\text { through your class? }\end{array}$ \\
\hline
\end{tabular}




\section{REFERENCES}

1. Association for the Advancement of Collegiate Schools of Business-International. (2004, January 1). Eligibility and accreditation standards for business accreditation (Adopted April 25, 2003; revised January 1, 2004). Retrieved June 27, 2004 from http://www.aacsb.edu/accreditation/business/standards01-01-04.pdf.

2. Bennett, N., Dunne, E., \& Carré, C. (2000). Skills Development in Higher Education and Employment. Buckingham: SHRE/Open University Press.

3. Billing, D. (2003). "Generic cognitive abilities in higher education: An international analysis of skills sought by stakeholders". Compare: A Journal of Comparative Education. 33(3), 335-351.

4. Dench, Sally. 1997. "Changing skill needs: What makes people employable?" Industrial and Commercial Training. 29(6), 190-193.

5. Swenson, D.H. (1980). "Relative importance of business communication skills for the next ten years". Journal of Business Communication, 17(2) 42-51.

6. Tanyel, F., Mitchell, M.A., \& McAlum, H.G. (1999). "The skill set for success of new business school graduates: Do prospective employers and university faculty agree?" Journal of Education for Business, September/October, 33-37.

7. Waner, K.K. (1995). "Business communication competencies needed by employees as perceived by business faculty and business professionals". Business Communication Quarterly, 58(4), 51-56.

8. Wardrope, W.J. (2000). "Department chairs' perceptions of the importance of business communication skills”. Business Communication Quarterly, 65(4) 60-72.

9. Wardrope, W.J., \& Bayless, M.L. (1999). "Content of the business communication course: An analysis of coverage”. Business Communication Quarterly, 62(4), 33-40.

\section{NOTES}

